\title{
Peran Pola Asuh Autoritatif dan Konsep Diri terhadap Self regulated learning Siswa Remaja SMA di Kabupaten Gianyar
}

\author{
Putu Deasytha Purwarini dan I Made Rustika \\ Program Studi Psikologi, Fakultas Kedokteran, Universitas Udayana \\ deasythapurwarini@gmail.com
}

\begin{abstract}
Abstrak
Self-regulated learning merupakan aspek mental yang sangat penting dalam kehidupan remaja yang sedang menuntut ilmu karena pada masa remaja terjadi banyak gejolak, seperti emosi, teman sebaya, identitas diri, dan kognitif. Selfregulated learning merupakan sebuah konsep bagaimana individu menjadi pengatur bagi belajarnya sendiri. Self regulated learning bukan aspek mental yang dibawa sejak lahir melainkan dipengaruhi oleh faktor internal dan eksternal. Bagaimana seseorang memandang dirinya serta bagaimana lingkungan memperlakukan seseorang sejak usia dini akan memengaruhi perkembangan Self regulated learning. Konsep diri merupakan salah satu faktor internal dan pola asuh autoritatif merupakan salah satu faktor eksternal yang memengaruhi Self regulated learning. Tujuan dari penelitian ini adalah untuk mengetahui peran pola asuh autoritatif dan konsep diri terhadap Self-regulated learning. Subjek penelitian berjumlah 220 siswa SMA yang terpilih melalui two stage cluster sampling. Hasil uji regresi berganda menunjukkan nilai R sebesar 0,587 dan R Square sebesar 0,344, yang berarti bahwa pola asuh autoritatif dan konsep diri secara bersama-sama berperan sebesar 34,4\% terhadap Self regulated learning. Koefisien beta terstandarisasi dari pola asuh autoritatif sebesar 0,100 dan taraf signifikansi $0,107(p>0,05)$ menunjukkan bahwa pola asuh autoritatif tidak berperan secara signifikan terhadap Self regulated learning. Koefisien beta terstandarisasi dari konsep diri sebesar 0,535 dan taraf signifikansi $0,000(\mathrm{p}<0,05)$ menunjukkan bahwa konsep diri berperan secara signifikan terhadap Self regulated learning.
\end{abstract}

Kata kunci : pola asuh autoritatif, konsep diri, Self regulated learning, remaja.

\begin{abstract}
Self-regulated learning is a very important mental aspect in the life of adolescents in high school because in adolescence there are a lot of fluctuations that seems to occur, such as emotions, peers, identity, and cognitive. Selfregulated learning is a concept of how individuals become the regulator of the individuals' learning program. Selfregulated learning is not a mental aspect that is brought on from birth, otherwise, it is influenced by internal and external factors. How an individual sees themselves as a person and how the environment treats the individual from their early age will affect the development of the individual's self- regulated learning. Self-concept, as an internal factor, as well as authoritative parenting as an external factor, may influence individual's self-regulated learning. The purpose of this study is to understand how authoritative parenting and self-concept influence individual's self-regulated learning. The subjects of this study amounted to 220 high school students who were selected through two stage cluster sampling. The result of multiple regression test shows that $\mathrm{R}$ value is 0,587 and $\mathrm{R}$ Square is 0,344 , which means that authoritative parenting and self-concept have contributed to affect individual's self-regulated learning by $34,4 \%$. The standardized beta coefficient of authoritative parenting by 0.100 and the significance level by $0.107(\mathrm{p}>0.05)$ indicate that authoritative parenting does not play a significant role in self-regulated learning. Standardized beta coefficient of self-concept by 0,535 and significance level by $0,000(p<0,05)$ indicate that self-concept have a significant role to selfregulated learning.
\end{abstract}

Keywords: authoritative parenting, self-concept, self-regulated learning, adolescent. 


\section{LATAR BELAKANG}

Self regulated learning merupakan sebuah konsep mengenai bagaimana individu menjadi pengatur bagi belajarnya sendiri. Self regulated learning bukan kemampuan mental seperti inteligensi atau kemampuan akademik tetapi lebih kepada proses mengarahkan diri untuk mengubah kemampuan mental menjadi kemampuan akademik (Zimmerman \& MartinezPons, 1988). Pintrich (dalam Schunk, 2005) menjelaskan bahwa Self regulated learning merupakan proses aktif dan konstruktif dimana siswa menetapkan tujuan untuk pembelajaran dan kemudian berusaha untuk memonitor, mengatur, dan mengendalikan kognisi, motivasi serta perilaku. Siswa yang mampu mengendalikan kognisi, motivasi, serta perilaku, maka siswa akan mampu mencapai tujuan yang sudah ditetapkan.

Santrock (2007) menyebutkan ada lima karakteristik dari Self regulated learning, yaitu individu menetapkan tujuan untuk memperluas pengetahuan dan membina motivasi. Individu memahami sifat dasar dari emosinya dan membuat strategistrategi yang akan digunakan untuk mengelola emosi. Rutin mengontrol kemajuan yang telah dicapai dalam meraih tujuan. Memperbaiki strategi-strategi sesuai dengan kemajuan yang telah dicapai. Mengevaluasi hambatan-hambatan dan berusaha untuk melakukan adaptasi. Self regulated learning penting bagi siswa karena membantu siswa dalam proses belajar dan meraih tujuan yang ingin dicapai. Siswa yang mampu mengembangkan Self regulated learning akan berusaha sebaik mungkin untuk mengerjakan tugas yang diberikan walaupun tugas tersebut adalah tugas yang sulit. Siswa juga akan mengubah cara belajarnya jika mendapat prestasi yang rendah. Sebagai contoh jika remaja mendapat nilai yang rendah pada saat ujian kenaikan kelas, maka siswa akan mengubah cara belajarnya. Siswa yang dulunya hanya belajar sehari sebelum ujian, maka setelah mendapat nilai rendah siswa akan belajar setiap hari dan banyak berlatih mengerjakan soal-soal sehingga saat ujian kenaikan kelas berikutnya siswa bisa mendapat nilai yang baik.

Siswa yang tidak mampu mengembangkan Self regulated learning tidak akan bisa mengubah cara belajarnya walaupun mendapat prestasi yang rendah. Sebagai contoh jika siswa mendapat nilai yang rendah saat ujian kenaikan kelas karena baru belajar sehari sebelum ujian, maka pada ujian kenaikan kelas berikutnya siswa akan terus mengulangi cara belajarnya tersebut. Siswa yang tidak mampu mengembangkan Self regulated learning akan terus mendapat nilai atau prestasi yang rendah. Siswa yang memiliki Self regulated learning yang rendah akan mudah menyerah dalam menyelesaikan tugas yang dianggapnya sulit untuk dikerjakan. Pemaparan tersebut sejalan dengan hasil penelitian dari Mulyana, Bashori, dan Mujidin (2015). Hasil penelitiannya menunjukkan bahwa siswa yang memiliki kemampuan Self regulated learning yang tinggi akan berusaha mencoba setiap tugas yang diberikan meskipun sulit untuk dikerjakan. Siswa akan meningkatkan usahanya apabila terjadi suatu kegagalan, sehingga siswa dapat berhasil. Siswa terdorong untuk merencanakan, mengatur, memonitor, mengevaluasi bahkan memanfaatkan lingkungan untuk mendukung aktivitas belajarnya. Hasil penelitian tersebut juga memaparkan bahwa siswa yang memiliki kemampuan Self regulated learning yang rendah akan merasa enggan melakukan tugas yang diberikan apabila siswa tahu bahwa dirinya tidak mampu melakukannya, tanpa ada usaha. Keengganan tersebut membuat siswa tidak mampu merencanakan atau mengatur pikiran, perilaku, dan emosinya yang menyebabkan siswa cenderung defensif seperti memilih membolos, menyontek dan sebagainya.

Penelitian Self regulated learning yang dilakukan oleh Ruliyanti dan Laksmiwati (2014) menegakkan siswa yang memiliki Self regulated learning yang tinggi akan berpeluang untuk mendapatkan prestasi yang baik dibandingkan dengan siswa yang memiliki Self regulated learning rendah. Self regulated learning memiliki kontribusi yang dominan dalam meningkatkan prestasi. Hal tersebut disebabkan karena siswa yang memiliki Self regulated learning mempunyai strategi untuk mengolah informasi yang baik dalam menerima materi. Siswa juga biasanya memiliki catatan yang rapi dan lengkap sehingga materi pelajaran menjadi mudah untuk dipelajari, cenderung mengontrol perilaku belajarnya sendiri seperti mengatur waktu dan lingkungan belajarnya sendiri, serta memiliki pengelolaan emosi yang baik seperti membangkitkan usaha ketika menghadapi kegagalan.

Self regulated learning sangat penting dalam kehidupan manusia, terlebih lagi bagi remaja yang sedang menuntut ilmu karena pada masa remaja terjadi banyak gejolak, seperti emosi, teman sebaya, identitas diri, dan kognitif. Ali dan Asrori (2014) mengemukakan bahwa masa remaja memiliki emosi yang fluktuatif sedangkan pengendalian diri remaja belum sempurna, perubahan emosi remaja terlihat jelas pada perubahan perilakunya, seperti agresif, rasa takut yang berlebihan, dan sikap apatis. Santrock (2007) mengatakan bahwa remaja memiliki kebutuhan yang kuat untuk disukai dan diterima oleh teman sebaya, remaja akan merasa senang apabila diterima oleh teman sebaya dan sebaliknya akan merasa sangat tertekan serta cemas apabila dikeluarkan dan diremehkan oleh teman sebayanya. Menurut Erikson (dalam Santrock 2007) identitas versus kebingungan identitas merupakan krisis psikososial selama masa remaja. Ketika remaja dihadapkan pada peran-peran baru, remaja mengalami psychosocial moratorium yaitu istilah yang digunakan Erikson untuk merujuk pada kesenjangan antara rasa aman masa kanak-kanak dengan otonomi yang dialami remaja sebagai bagsiswan dari eksplorasi identitasnya. Remaja yang tidak berhasil mengatasi krisis identitas akan mengalami kebingungan identitas (identity confusion). Santrock (2002) menyatakan bahwa tahap perkembangan kognitif remaja adalah tahap pemikiran operasional formal dimana remaja tidak lagi terbatas pada pengalaman konkret aktual sebagai dasar pemikiran. Sebaliknya, remaja dapat membangkitkan situasi-situasi khayalan, kemungkinan-kemungkinan hipotesis, atau dalil-dalil penalaran yang benar-benar abstrak.

Siswa yang mampu mengembangkan Self regulated learning yang tinggi akan mampu mendapatkan prestasi yang baik, seperti siswa SMA di Kabupaten Gianyar pada tahun 2013 berhasil lulus $100 \%$ pada ujian nasional dan juga meraih rangking 10 besar di Provinsi Bali. Sekolah SMA yang berhasil masuk rangking 10 besar yaitu SMAN 1 Sukawati pada peringkat 6, SMAN 1 Ubud peringkat 8, dan SMAN 1 Blahbatuh pada peringkat 9 untuk jurusan bahasa. SMAN 1 Gianyar berhasil meraih 6 pada jurusan IPA (Putu, 2013). 
Tahun ajaran 2015/2016 Kabupaten Gianyar kembali meraih rangking 10 besar nilai ujian nasional di Provinsi Bali. SMAN 1 Sukawati berhasil meraih peringkat 7 pada jurusan bahasa dengan tottal nilai rata-rata 428,30 dan salah seorang siswanya mampu meraih 3 besar nilai ujian nasional tertinggi yaitu pada peringkat pertama dengan jumlah nilai 525,5. SMAN 1 Gianyar berhasil meraih peringkat 2 pada jurusan IPA dengan total nilai rata-rata 494,14 dan berhasil masuk 3 besar nilai nasional tertinggi yaitu pada peringkat ketiga dengan jumlah nilai 559,5. SMAN 1 Gianyar berhasil meraih peringkat 3 pada jurusan IPS dengan total nilai rata-rata 450,57 (Disdikpora Bali, 2016).

Studi pendahuluan yang dilakukan pada 50 orang siswa SMA kelas X dan XII di Gianyar, menyatakan bahwa sebanyak 44 siswa mengalami hambatan dalam menetapkan dan mencapai tujuan belajar. Hambatan yang paling banyak dialami oleh siswa yang sulit dalam mengatur jadwal belajar yaitu sebanyak 16 orang siswa. Sebanyak 13 siswa menyatakan hambatan dalam proses belajar yaitu sulit dalam mengatur startegi belajar. Sulit dalam memahami materi pelajaran juga menjadi hambatan bagi 15 siswa. Terlalu banyak mengambil kegiatan diluar jam pelajaraan seperti mengikuti organisasi dan membantu orangtua menjadi hambatan dalam proses belajar bagi 10 siswa. Dampak yang dialami oleh para siswa akibat dari hambatan tersebut adalah rendahnya keinginan untuk belajar yang dinyatakan oleh 25 orang siswa. Sebanyak 12 siswa menyatakan bahwa dirinya menjadi tidak percaya diri. Dampak lain yang juga dialami adalah bersikap pesimis dimana hal ini dialami oleh 11 orang siswa. Sebanyak 7 orang siswa mengatakan bahwa dampak yang dirasakan akibat dari hambatan tersebut adalah tidak berani mencoba hal-hal baru.

Berdasarkan pemaparan diatas, peneliti tertarik untuk mengetahui mengapa ada siswa yang memiliki Self regulated learning yang tinggi sedangkan yang lainnya tidak? Self regulated learning bukan aspek mental yang dibawa sejak lahir melainkan dipengaruhi oleh beberapa faktor, salah satunya adalah faktor lingkungan. Faktor lingkungan yang memengaruhi Self regulated learning bisa berasal dari lingkungan keluarga. Kemampuan siswa dalam menggunakan Self regulated learning yang baik erat kaitannya dengan lingkungan rumah yang membantu anak mengembangkan kemampuan belajarnya dengan lebih baik. Lestari (2012) menjelaskan bahwa keluarga merupakan unit sosial terkecil dalam masyarakat, akan tetapi keluarga memiliki peran yang besar dalam perkembangan anak. Fungsi dari sebuah keluarga adalah merawat dan mengasuh anak. Pola asuh memiliki peranan yang besar terhadap perkembangan manusia, karena pola asuh merupakan perlakuan langsung yang diterima oleh manusia sejak dini.

Pola asuh memiliki dampak bagi perkembangan remaja karena pola asuh merupakan serangkaian sikap atau perilaku yang ditunjukkan oleh orangtua kepada anaknya. Sikap dan perilaku orangtua yang terbuka pada anak akan membantu anak untuk mengembangkan Self regulated learning. Salah satu pola asuh yang baik adalah pola asuh autoritatif. Orangtua dengan pola asuh autoritatif mendorong individualitas dan kemandirian, orangtua memuji perilaku dan prestasi anak yang baik, dan mengkritik tindakan anak yang memerlukan perubahan (Baumrind dalam Spring 2008). Kopko (2007) mengungkapkan bahwa orangtua yang menerapkan pola asuh autoritatif mendorong remaja untuk mandiri dengan tetap menjaga batas dan kontrol pada tindakan.

Santrock (2007) menyatakan orangtua dengan pola asuh autoritatif mengharapkan perilaku anak yang dewasa, mandiri, serta sesuai dengan usia anak. Anak yang memiliki orangtua autoritatif mampu mengendalikan diri, mandiri, ceria, dan memiliki prestasi yang baik. Papalia, Old, dan Feldman (2010) menyatakan bahwa anak dengan orangtua autoritatif akan merasa aman karena anak tahu bahwa dirinya dicintai oleh kedua orangtuanya. Anak-anak juga akan cenderung independen, asertif, dan terkontrol. Lestari (2012) menambahkan bahwa anak dengan pola asuh autoritatif akan cenderung periang, percaya diri, dan lebih kooperatif.

Penelitian yang dilakukan oleh Ellena dan Leonardi (2014) menegakkan bahwa pola asuh autoritatif memiliki peran yang besar jika dibandingkan dengan pola asuh lainnya. Kebutuhan individu di masa remaja dapat diakomodir dengan kesempatan untuk mandiri yang diberikan oleh orangtua. Selama proses belajar, remaja berusaha menggunakan kepercayaan yang diberikan oleh orangtua, berusaha untuk mandiri, dan bertanggung jawab atas keputusan yang diambil. Remaja dengan pola asuh autoritatif memiliki prediksi keberhasilan dengan kemampuan Self regulated learning yang tinggi.

Faktor lain yang dapat memengaruhi Self regulated learning selain faktor lingkungan adalah penilaian diri. Individu yang mampu menilai keadaan dirinya dengan baik, maka akan mengenali kemampuan, kelebihan, dan kekurangan yang dimilikinya, penilaian diri sama dengan konsep diri. Menurut Taylor (2009) konsep diri merupakan salah satu aspek yang memengaruhi pemikiran dan perilaku individu. Agustiani (2009) mengungkapkan bahwa konsep diri merupakan gambaran yang dimiliki seseorang tentang dirinya, yang dibentuk melalui pengalaman-pengalaman. Konsep diri sudah dibentuk dan ditanamkan sejak masa kana-kanak dimana nantinya konsep diri akan berpengaruh pada tingkah laku individu di masa selanjutnya.

Fits (dalam Agustiani, 2009) menjelaskan bahwa konsep diri berpengaruh kuat terhadap tingkah laku individu. Individu yang mempersepsikan dirinya inferior (rendah diri), maka tingkah laku yang ditampilkan akan tidak maksimal. Individu yang memandang dirinya sebagai seorang yang memiliki kemampuan untuk melaksanakan suatu tugas, maka individu tersebut akan menampilkan perilaku atau usaha yang besar agar dapat menyelesaikan tugas tersebut. Sebaliknya, apabila individu memandang dirinya sebagai seorang yang kurang memiliki kemampuan utuk melaksanakan suatu tugas maka usaha yang ditampilkan juga tidak maksimal dan individu akan mudah menyerah.

Penelitian yang dilakukan oleh Situmorang dan Latifah (2014) mengungkapkan bahwa konsep diri memiliki pengaruh yang positif terhadap strategi pengaturan diri dalam belajar. Konsep diri merupakan indikator utama dalam strategi pengaturan diri 
dalam belajar. Apabila seseorang memiliki pengetahuan dan persepsi mengenai kemampuan diri dalam mencapai sesuatu, maka individu akan menggunakan strategi yang tepat untuk mencapai tujuannya.

Siswa yang memiliki konsep diri yang positif akan mampu untuk mengembangkan Self regulated learning. Apabila seorang siswa memiliki konsep diri yang positif maka saat mengalami kegagalan atau mendapat nilai yang rendah, siswa tersebut mampu untuk berusaha lebih lagi. Siswa akan memperbaiki cara belajarnya dan tidak mudah menyerah. Sebaliknya, giat jika seorang siswa memiliki konsep diri yang negatif maka siswa tersebut tidak mampu mengembangkan Self regulated learning. Sebagai contoh apabila siswa mengalami kegagalan dan mendapat nilai yang rendah, maka siswa akan putus asa dan tidak mengubah cara belajarnya.

Berdasarkan pemaparan mengenai pola asuh autoritatif dan konsep diri, dapat dirangkum bahwa peran pola asuh autoritatif dan konsep diri terhadap Self regulated learning siswa remaja SMA yaitu orangtua yang menerapkan pola asuh autoritatif mendorong kemandirian remaja. Konsep diri merupakan gambaran yang dimiliki seseorang terhadap dirinya sehingga konsep diri menjadi salah satu aspek yang memengaruhi pemikiran dan perilaku. Remaja yang diasuh dengan pola asuh autoritatif dan memiliki konsep diri yang positif akan mampu untuk mengatur perilakunya sendiri termasuk mengatur jadwal belajar dan strategi belajarnya sendiri. Remaja yang tidak mampu mengembangkan Self regulated learning yang baik maka remaja akan bersikap pesimis, tidak percaya diri, dan tidak mampu meraih prestasi yang baik karena remaja tidak mampu mengatur strategi belajarnya dengan baik. Dengan demikian, peneliti ingin meneliti tentang peran pola asuh autoritatif dan konsep diri terhadap Self regulated learning siswa remaja SMA di Kabupaten Gianyar.

\section{METODE PENELITIAN}

\section{Variabel dan Definisi Operasional}

Variabel bebas dalam penelitian ini adalah pola asuh autoritatif dan konsep diri, serta variabel tergantung dalam penelitian ini adalah Self regulated learning. Definisi operasional variabel penelitian ini, adalah :

\section{$\underline{\text { Pola Asuh Autoritatif }}$}

Pola asuh autoritatif merupakan pola asuh yang memiliki tingkat demandingness (kontrol) dan responsiveness (kehangatan) yang seimbang, hal tersebut dapat dilihat dari kehangatan interaksi orangtua dengan anak, tegas dalam mengarahkan perilaku anak, tanggap memenuhi perilaku anak, dan menetapkan perilaku yang diharapkan. Taraf pola asuh autoritatif diukur dengan skala pola asuh autoritatif, semakin tinggi skor total yang diperoleh maka semakin tinggi taraf pola asuh autoritatif.

Konsep Diri

Konsep diri merupakan gambaran yang dimiliki seseorang tentang dirinya, yang dibentuk melalui pengalamanpengalaman yang diperoleh dari interaksi dengan lingkungan yang meliputi penilaian internal (diri identitas, diri pelaku, diri penerimaan atau penilai) dan penilaian eksternal (diri fisik, diri etik-moral, diri pribadi, diri keluarga, dan diri sosial). Taraf konsep diri diukur dengan skala konsep diri, semakin tinggi skor total yang diperoleh maka semakin tinggi taraf konsep diri.

Self regulated learning

Self regulated learning merupakan proses aktif dan konstruktif dimana siswa menetapkan tujuan untuk pembelajaran dan kemudian berusaha untuk memonitor, mengatur, dan mengendalikan kognisi, motivasi serta perilaku. Taraf Self regulated learning diukur dengan skala Self regulated learning, semakin tinggi skor total yang diperoleh maka semakin tinggi taraf Self regulated learning.

\section{Responden}

Responden dalam penelitian ini adalah siswa SMA di Kabupaten Gianyar. Karakteristik subjek penelitian yang digunakan adalah siswa yang berusia 15 hingga 18 tahun, tinggal bersama kedua orangtuanya, dan siswa yang tercatat sebagai siswa SMA di Kabupaten Gianyar.

Teknik sampling yang digunakan adalah teknik two stage cluster sampling yaitu teknik pengambilan sampel dengan menggunakan dua tahap. Pada tahap pertama dilakukan pemilihan primary sampling unit yaitu dengan melakukan pemilihan SMA yang ada di Kabupaten Gianyar. Pada tahap kedua dilakukan pemilihan untuk elementer yang ada dalam primary sampling unit, dimana dalam hal ini unit elementer yang dimaksud adalah kelas yang ada di SMA yang terpilih (Nazir, 1988). Menurut Azwar (2013) jumlah ukuran sampel untuk penelitian adalah minimal 60 .

\section{Tempat Penelitian}

Penelitian ini dilakukan di SMA Negeri 1 Blahbatuh yang terletak di Kabupaten Gianyar pada bulan Mei 2017. Dari 10 kelas XI dan 10 kelas X yang di random, maka terpilih 7 kelas yaitu kelas XI IPA 1, XI IPA 2, XI IPA 4, XI IPA 5, X IPA 2, X IPA 4, dan X IPS 2.

\section{Alat Ukur}

Alat ukur yang digunakan dalam penelitian ini adalah skala, dimana dalam skala yang digunakan terdapat pernyataanpernyataan yang favorable dan unfavorable. Pernyataan favorable merupakan pernyataan yang positif dan unfavorable adalah pernyataan yang negatif. Penilaian jawaban subjek disesuaikan dengan kalimat positif dan negatif yang disusun dalam pernyataan pada skala penelitian ini. Penilaian jawaban subjek dapat dilihat pada tabel 1 (terlampir).

Dalam penelitian ini peneliti menggunakan tiga skala yaitu skala pola asuh autoritatif, konsep diri, dan Self regulated learning.

$\underline{\text { Skala Pola Asuh Autoritatif }}$

Skala pola asuh autoritatif dalam penelitian ini, memodifikasi yang dilakukan dengan menambahkan beberapa aitem pada skala pola asuh autoritatif yang disusun oleh Rustika (2014). Skala pola asuh autoritatif disusun berdasarkan aspek-aspek pola asuh autoritatif, yaitu kehangatan interaksi orangtua dengan anak, tegas dalam mengarahkan perilaku anak, tanggap memenuhi perilaku anak, dan menetapkan perilaku yang diharapkan. Skala pola asuh autoritatif yang disusun oleh 
Rustika memiliki nilai koefisien reliabilitas sebesar 0,901 . Hasil tersebut menggambarkan bahwa skala pola asuh autoritatif dapat digunakan untuk mengukur pola asuh autoritatif.

\section{Skala Konsep diri}

Skala konsep diri yang digunakan dalam penelitian ini adalah skala konsep diri yang disusun oleh peneliti. Skala konsep diri disusun berdasarkan dimensi internal dan dimensi eksternal konsep diri yang dikemukakan oleh Fits (dalam Agustiani, 2009).

\section{Skala Self regulated learning}

Skala Self regulated learning yang digunakan dalam penelitian ini memodifikasi yang dilakukan dengan menambahkan dan mengurangkan beberapa aitem pada skala yang disusun oleh Putri (2015). Skala Self regulated learning disusun berdasarkan dimensi Self regulated learning. Skala Self regulated learning yang disusun oleh Putri memiliki nilai koefisien reliabilitas sebesar 0,872. Hasil tersebut menggambarkan bahwa skala Self regulated learning dapat digunakan untuk mengukur Self regulated learning.

Uji validitas pada penelitian ini dilakukan dengan mengeliminasi skor corrected total aitem correlation yang kurang dari 0,25 . Uji reliabilitas dalam penelitian ini adalah dengan menggunakan Cronbach's Alpha, dimana alat ukur dapat dikatakan reliabel apabila koefisien reliabilitasnya lebih tinggi dari 0,60 .

Hasil uji validitas yang dilakukan pada 30 aitem skala pola asuh autoritatif menghasilkan 3 aitem gugur dan 27 aitem valid. Aitem yang valid memiliki koefisien korelasi aitem total berkisar dari 0,275 sampai 0,665. Hasil uji reliabilitas skala pola asuh autoritatif dengan menggunakan alpha cronbach $(\alpha)$ adalah sebesar 0,906. Koefisien reliabilitas sebesar 0,906 menunjukkan bahwa skala ini mampu mencerminkan 90,6\% variasi skor subjek adalah skor murni. Hasil tersebut menggambarkan bahwa skala pola asuh autoritatif dapat digunakan untuk mengukur pola asuh autoritatif.

Hasil uji validitas yang dilakukan pada 48 aitem skala konsep diri menghasilkan 11 aitem gugur dan 37 aitem valid. Aitem yang valid memiliki koefisien korelasi aitem total berkisar dari 0,255 sampai 0,589. Hasil uji reliabilitas skala konsep diri dengan menggunakan alpha cronbach $(\alpha)$ adalah sebesar 0,910. Koefisien reliabilitas sebesar 0,910 menunjukkan bahwa skala ini mampu mencerminkan 91,0\% variasi skor subjek adalah skor murni. Hasil tersebut menggambarkan bahwa skala konsep diri dapat digunakan untuk mengukur konsep diri.

Hasil uji validitas yang dilakukan pada 30 aitem skala Self regulated learning menghasilkan 3 aitem gugur dan 32 aitem valid. Aitem yang valid memiliki koefisien korelasi aitem total berkisar dari 0,252 sampai 0,622. Hasil uji reliabilitas skala Self regulated learning dengan menggunakan alpha cronbach $(\alpha)$ adalah sebesar 0,889 . Koefisien reliabilitas sebesar 0,889 menunjukkan bahwa skala ini mampu mencerminkan $88,9 \%$ variasi skor subjek adalah skor murni. Hasil tersebut menggambarkan bahwa skala Self regulated learning dapat digunakan untuk mengukur Self regulated learning.

\section{Teknik Analisis Data}

Uji hipotesis penelitian dapat dilakukan apabila telah melewati syarat-syarat uji asumsi yaitu uji normalitas, uji linearitas, dan uji multikolinearitas. Uji normalitas dilakukan dengan menggunakan uji Kolgomorov-Smirnov, data dapat dikatakan terdistribusi normal apabila hasil probabilitas $\mathrm{p}>0,05$ (Yudiaatmaja, 2013). Uji linearitas yang digunakan dalam penelitian ini adalah uji compare mean dengan melihat nilai signifikansi pada Linearity dibawah $0.05(\mathrm{p}<0.05)$ atau dengan melihat nilai signifikansi pada Deviation from Linearity diatas 0.05 ( $p>0.05)$, maka antara variabel bebas dan variabel tergantung memiliki hubungan yang linear (Gunawan, 2013). Uji multikolinearitas adalah uji untuk melihat korelasi antar variabel bebas, uji multikolinearitas dapat dilihat dari nilai variance inflation factor (VIF) dan nilai tolerance. Jika nilai $\mathrm{VIF} \leq 10$ dan collinierity tolerance $\geq 0,1$, maka dinyatakan tidak terjadi multikolinearitas (Yudiaatmaja, 2013).

\section{HASIL PENELITIAN}

\section{Karakteristik Subjek}

Subjek dalam penelitian ini adalah remaja pertengahan berusia 15 sampai 18 tahun yang sedang menempuh pendidikan di SMA Negeri 1 Blahbatuh dan berjumlah 220 subjek. Mayoritas subjek yang mengikuti penelitian ini berada pada usia 16 tahun sebanyak 118 atau sekitar 53,64\%, berjenis kelamin perempuan sebanyak 120 atau sekitar 54,5\%, berada pada kelas XI sebanyak 116 atau sekitar 52,7\%, dan berada pada jurusan IPA sebanyak 189 atau sekitar $86,0 \%$.

Mayoritas subjek yang mengikuti penelitian ini memiliki ayah yang berpendidikan menengah sebanyak 125 atau sekitar $56,83 \%$, dan ibu yang berpendidikan menengah sebanyak 139 atau sekitar $63,17 \%$. Mayoritas subjek memiliki ayah yang berprofesi sebagai swasta sebanyak 155 atau sekitar 70,41\%, dan memiliki ibu yang berprofesi sebagai swasta sebanyak 119 atau sekitar 54,099\% dari total keseluruhan subjek.

\section{Deskripsi Dan Kategorisasi Data Penelitian}

Hasil deskripsi data penelitian yaitu pola asuh autoritatif, konsep diri, dan Self regulated learning dapat dilihat pada tabel 2 (terlampir).

Dari hasil deskripsi data penelitian pada tabel 2, dapat dijelaskan makna-makna dari hasil tersebut sebagai berikut :

Pola asuh autoritatif

Variabel pola asuh autoritatif memiliki nilai mean teoretis sebesar 67,5 dan nilai mean empiris sebesar 89,83. Perbedaan antara mean empiris dan mean teoretis sebesar 22,33, dengan nilai $t$ sebesar 36,629 $(\mathrm{p}=0,000)$. Hal ini menunjukkan perbedaan yang signifikan antara mean empiris dan mean teoretis (mean empiris $>$ mean teoretis) sehingga dapat disimpulkan bahwa subjek memiliki pola asuh autoritatif yang tinggi. Rentang skor subjek penelitian yaitu antara 42 sampai dengan 108. Berdasarkan penyebaran frekuensi, hampir $100 \%$ subjek pada penelitian ini berada di atas mean teoretis.

Hasil dari kategorisasi variabel pola asuh autoritatif menunjukkan bahwa subjek yang memiliki pola asuh 
autoritatif sangat tinggi sebanyak 134 orang (60,91\%) (Tabel 3. Kategorisasi pola asuh autoritatif. Terlampir).

Konsep diri

Variabel konsep diri memiliki nilai mean teoretis sebesar 92,5 dan nilai mean empiris sebesar 110,79. Perbedaan antara mean empiris dan mean teoretis sebesar 18,29, dengan nilai t sebesar $23,961(p=0,000)$. Hal ini menunjukkan perbedaan yang signifikan antara mean empiris dan nilai mean teoretis (mean empiris $>$ mean teoretis) sehingga dapat disimpulkan bahwa subjek memiliki konsep diri yang tinggi. Rentang skor subjek penelitian yaitu antara 85 sampai dengan 146. Berdasarkan penyebaran frekuensi, $100 \%$ subjek pada penelitian ini berada di atas mean teoretis.

Hasil dari kategorisasi variabel konsep diri menunjukkan bahwa subjek yang memiliki konsep diri tinggi sebanyak 142 orang $(64,54 \%)$ (Tabel 4. Kategorisasi Konsep Diri. Terlampir).

\section{Self regulated learning}

Variabel Self regulated learning memiliki nilai mean teoretis sebesar 80 dan nilai mean empiris sebesar 93,58. Perbedaan antara mean empiris dan mean teoretis sebesar 13,58, dengan nilai $t$ sebesar 20,264 $(p=0,000)$. Hal ini menunjukkan perbedaan yang signifikan antara mean empiris dan nilai mean teoretis (mean empiris $>$ mean teoretis) sehingga dapat disimpulkan bahwa subjek memiliki Self regulated learning yang tinggi. Rentang skor subjek penelitian yaitu antara 69 sampai dengan 125. Berdasarkan penyebaran frekuensi, hampir $100 \%$ subjek pada penelitian ini berada di atas mean teoretis.

Hasil dari kategorisasi variabel Self regulated learning menunjukkan bahwa subjek yang memiliki Self regulated learning tinggi 124 orang (56,36\%) (tabel 5. Kategorisasi Self regulated learning. Terlampir).

\section{Uji Asumsi}

Uji asumsi yang dilakukan pada penelitian ini adalah :

Uji Normalitas

Uji normalitas dilakukan untuk mengetahui apakah sebaran data variabel bebas dan variabel tergantung dapat dikatakan berdistribusi normal atau tidak. Uji normalitas dilakukan dengan menggunakan uji Kolgomorov-Smirnov. Data dapat dikatakan terdistribusi normal apabila hasil probabilitas p >0,05 (Yudiaatmaja, 2013)

Berdasarkan tabel 6 (terlampir), dapat dilihat bahwa variabel pola asuh autoritatif mempunyai nilai kolmogorov-smirnov 0,847 dengan nilai signifikansi $0,470(p>0,05)$, yang berarti bahwa data variabel pola asuh autoritatif berdistribusi normal. Variabel konsep diri mempunyai nilai kolmogorov-smirnov 0,877 dengan nilai signifikansi $0,426(p>0,05)$, yang berarti bahwa data variabel konsep diri berdistribusi normal. Variabel Self regulated learning mempunyai nilai kolmogorov-smirnov 1,227 dengan nilai signifikansi 0,099 ( $>>0,05)$, yang berarti bahwa data variabel Self regulated learning berdistribusi normal.

\section{Uji Linearitas}

Uji linearitas adalah uji yang digunakan untuk melihat adanya hubungan yang linear antara variabel bebas dengan variabel tergantung (Ghozali, 2005). Uji linearitas yang digunakan dalam penelitian ini adalah uji compare mean dengan melihat nilai signifikansi pada Linearity dibawah $0.05(\mathrm{p}<0.05)$ atau dengan melihat nilai signifikansi pada Deviation from Linearity diatas 0.05 ( $>0.05$ ) (Gunawan, 2013).

Berdasarkan tabel 7 (terlampir), dapat dilihat bahwa nilai Linearity $0,000 \quad(\mathrm{p}<0,05)$, yang berarti bahwa terdapat hubungan yang linear antara Self regulated learning dengan pola asuh autoritatif dan terdapat hubungan yang linear antara Self regulated learning dengan konsep diri.

Uji Multikolinearitas

Uji multikolinearitas adalah uji untuk melihat korelasi antar variabel bebas. Menurut Ghozali (2011) uji multikolinearitas dapat dilihat dari nilai variance inflation factor (VIF) dan nilai tolerance. Yudiaatmaja (2013) menyatakan bahwa, jika nilai $\mathrm{VIF} \leq 10$ dan collinierity tolerance $\geq 0,1$, maka dinyatakan tidak terjadi multikolinearitas.

Tabel 8 (terlampir) menunjukkan bahwa tidak terjadi multikolinearitas antar variabel bebas yaitu pola asuh autoritatif dan konsep diri, karena nilai tolerance dari masingmasing variabel bebas adalah 0,798 lebih besar dari $0,1(0,798$ $>0,1)$ dan nilai variance inflation factor (VIF) dari masingmasing variabel bebas adalah 1,252 lebih kecil dari 10 (1,252 $<10)$.

\section{Uji Hipotesis}

Uji hipotesis pada penelitian ini dilakukan dengan menggunakan teknik regresi berganda. Hasil uji regresi berganda pola asuh autoritatif dan konsep diri terhadap Self regulated learning dapat dilihat pada tabel 9, 10, dan 11 (tabel 9-tabel 10-tabel 11. Terlampir).

Tabel 9 menunjukkan bahwa nilai $\mathrm{R}$ sebesar 0,587 dan $\mathrm{R}$ Square sebesar 0,344, maka dapat dikatakan bahwa pola asuh autoritatif dan konsep diri memiliki peran sebesar 34,4\% terhadap Self regulated learning, sedangkan $65,6 \%$ dipengaruhi oleh faktor lain yang tidak diteliti.

Tabel 10 menunjukkan bahwa nilai $\mathrm{F}$ hitung sebesar 57,004 dan nilai signifikansi sebesar 0,000 $(0,000<0,05)$, maka model regresi berganda dapat digunakan untuk memprediksi Self regulated learning dan dapat dikatakan bahwa pola asuh autoritatif dan konsep diri secara bersama-sama berperan terhadap Self regulated learning.

Tabel 11 menunjukkan bahwa variabel pola asuh autoritatif memiliki koefisien beta terstandarisasi 0,100 dan nilai $t$ sebesar 1,618 dengan nilai signifikansi 0,107 $(0.107>0,05)$ yang berarti bahwa pola asuh autoritatif tidak berperan secara signifikan terhadap Self regulated learning. Variabel konsep diri memiliki koefisien beta terstandarisasi 0,535 dan nilai $\mathrm{t}$ sebesar 8,705 dengan nilai signifikansi $0,000(0,000<0,05)$ yang berarti bahwa konsep diri berperan secara signifikan terhadap Self regulated learning.

\section{PEMBAHASAN DAN KESIMPULAN}

Berdasarkan hasil penelitian yang telah dilakukan dan 
dianalisis menggunakan teknik analisis regresi berganda, dapat dinyatakan bahwa hipotesis mayor yaitu pola asuh autoritatif dan konsep diri berperan terhadap Self regulated learning siswa remaja SMA di Kabupaten Gianyar, dapat diterima. Hal ini dapat dilihat dari koefisien $\mathrm{R}$ sebesar 0,587, $\mathrm{R}$ Square sebesar 0,344, F hitung sebesar 57,004, dan signifikansi 0,000 $(\mathrm{p}<0,05)$ yang menyatakan bahwa pola asuh autoritatif dan konsep diri secara bersama-sama berperan terhadap Self regulated learning. Nilai koefisien $\mathrm{R}$ Square sebesar 0,344, menunjukkan bahwa pola asuh autoritatif dan konsep diri memiliki peran sebesar $34,4 \%$ terhadap Self regulated learning remaja SMA di Gianyar, sedangkan 65,6\% dipengaruhi oleh faktor lain yang tidak diteliti dalam penelitian ini. Dari hasil koefisien beta terstandarisasi, dapat diketahui bahwa konsep diri berperan secara signifikan terhadap Self regulated learning dimana hal ini ditunjukkan dengan variabel konsep diri memiliki nilai koefisien beta terstandarisasi sebesar 0,535 dengan nilai t sebesar 8,705 dan signifikansi $0,000 \quad(p<0,05)$. Variabel pola asuh autoritatif tidak berperan secara signifikan terhadap Self regulated learning yang ditunjukkan dengan nilai beta terstandarisasi 0,100 dengan nilai $t$ sebesar 1,618 dan signifikansi 0,107 $(\mathrm{p}>0,05)$.

Pintrich (dalam Schunk 2005) menjelaskan bahwa Self regulated learning merupakan proses aktif dan konstruktif dimana siswa menetapkan tujuan untuk pembelajaran dan kemudian berusaha untuk memonitor, mengatur, dan mengendalikan kognisi, motivasi serta perilaku. Self regulated learning menekankan pentingnya tanggung jawab personal dan mengontrol pengetahuan serta keterampilan (Zimmerman, 1990). Mengontrol pengetahuan dan keterampilan akan bisa dilakukan apabila individu mampu menilai keadaan dirinya dengan baik, serta mampu mengenali kekurangan dan kelebihan yang ada. Dari hasil uji regresi, nilai koefisien terstandarisasi, nilai t, dan nilai signifikansi menunjukkan bahwa konsep diri berperan secara signifikan terhadap Self regulated learning. Konsep diri merupakan gambaran yang dimiliki seseorang tentang dirinya, yang dibentuk melalui pengalaman-pengalaman yang diperoleh dari interaksi dengan lingkungan (Agustiani, 2009). Fits (dalam Agustiani, 2009) menjelaskan bahwa konsep diri berpengaruh kuat terhadap tingkah laku individu. Jika individu mempersepsikan dirinya inferior (rendah diri), maka tingkah laku yang ditampilkan akan tidak maksimal. Sebaliknya, apabila individu yang memandang dirinya sebagai seorang yang memiliki kemampuan untuk melaksanakan suatu tugas, maka individu tersebut akan beusaha agar dapat menyelesaikan tugas tersebut.

Burns (1993) mengungkapkan bahwa terdapat dua bentuk konsep diri, yaitu konsep diri positif dan konsep diri negatif. Menurut Desmita (2009) individu dengan konsep diri yang positif berani mencoba hal-hal baru, optimis, percaya diri, antusias, berani sukses dan gagal, bersikap dan berpikir positif, serta berani menetapkan suatu tujuan. Sebaliknya, individu dengan konsep diri negatif cenderung tidak percaya diri sehingga merasa bahwa dirinya bodoh, takut mencoba halhal baru, dan merasa bahwa dirinya tidak berguna. Siswa yang memiliki konsep diri positif akan menetapkan suatu tujuan dan akan berusaha dengan baik untuk mencapai tujuan tersebut. Dalam mencapai suatu tujuan, siswa dengan konsep diri positif akan mencoba berbagai strategi dan jika gagal dengan strategi tersebut, maka siswa akan mencoba dengan strategi yang baru. Penelitian yang dilakukan oleh Setyani (2007) juga menjelaskan bahwa konsep diri positif merupakan pandangan keadaan diri dan individu merasa yakin dengan kemampuan yang dimiliki, sehingga hal tersebut akan memunculkan rasa percaya diri dan harga diri. Apabila seseorang memiliki konsep diri yang positif, maka siswa akan berusaha untuk mewujudkan tujuannya. Penelitian yang dilakukan oleh Situmorang dan Latifah (2014) mengungkapkan bahwa konsep diri merupakan indikator utama dalam strategi pengaturan diri dalam belajar. Apabila seseorang memiliki pengetahuan dan persepsi mengenai kemampuan diri dalam mencapai sesuatu, maka individu akan menggunakan strategi yang tepat untuk mencapai tujuannya. Penelitian yang dilakukan oleh Rini (2017) menambahkan bahwa terdapat hubungan yang positif antara konsep diri dengan kemandirian belajar siswa, sehingga semakin baik konsep diri maka semakin tinggi kemandirian belajar siswa.

Berdasarkan pembahasan mengenai konsep diri yang berperan secara signifikan terhadap Self regulated learning siswa Remaja SMA di Kabupaten Gianyar, dapat dirangkum bahwa siswa dengan konsep diri yang positif berani mencoba hal-hal baru, optimis, percaya diri, antusias, berani sukses dan gagal, bersikap dan berpikir positif, serta berani menetapkan suatu tujuan. Siswa dengan konsep diri positif akan mencoba berbagai strategi dan jika gagal dengan strategi tersebut, maka siswa akan mencoba dengan strategi yang baru.

Santrock (2007) menyatakan bahwa dalam memberi pengasuhan kepada anak, orangtua seringkali menggunakan kombinasi dari beberapa pola asuh yang ada, walaupun terdapat satu pola asuh dominan yang diterapkan oleh orangtua. Dari hasil uji regresi, nilai koefisien terstandarisasi, nilai $\mathrm{t}$, dan nilai signifikansi menunjukkan bahwa pola asuh autoritatif tidak berperan secara signifikan terhadap Self regulated learning. Pola asuh memiliki dampak bagi perkembangan anak karena pola asuh merupakan serangkaian sikap yang ditunjukkan oleh orangtua kepada anak untuk menciptakan emosi yang melingkupi interaksi antara orangtua dan anak. Orangtua yang menerapkan pola asuh autoritatif hangat, responsif, mendukung, tegas terhadap anak-anaknya, dan mendorong kemandirian anak (Baumrind, dalam Spring 2008). Pada masa remaja, peran orangtua tidak lagi seperti pada masa kanak-kanak, hal ini dikarenakan lingkungan pertemanan remaja semakin luas dan remaja cenderung lebih dekat dengan teman sebayanya.

Sarwono (2003) mengemukakan bahwa masa remaja merupakan masa pencarian identitas diri, sehingga remaja sering membantah orangtuanya karena remaja mulai mempunyai pendapat, nilai-nilai, cita-cita, dan sikap yang berbeda dengan orangtuanya. Bagi remaja, orangtua tidak dapat lagi dijadikan pegangan, oleh karena itu remaja menjadi lebih dekat dengan teman sebaya dan memperoleh dukungan sosial dari teman sebaya. Santrock (2007) mengungkapkan bahwa saat memasuki masa remaja, peran orangtua sedikit 
demi sedikit mulai berkurang, karena lingkungan sosial yang dihadapi remaja semakin luas dan terdapat kecenderungan bahwa remaja menghabiskan waktunya lebih banyak bersama teman sebaya dibandingkan orangtua. Remaja akan melihat dan meniru semua tindakan, gaya berpikir, dan tingkah laku yang dilakukan oleh teman sebayanya sehingga hal tersebut bisa memengaruhi Self regulated learning. Penelitian yang dilakukan oleh Mahmudi, Mayangsari, dan Rachmah (2007) menjelaskan bahwa semakin tinggi peer attachment maka semakin tinggi pula Self regulated learning. Penelitian lain mengenai self regulated lerning yang dilakukan oleh Fauziah (2007) mengungkapkan bahwa dukungan sosial yang diterima dari teman sebaya dapat menumbuhkan keyakinan dalam diri bahwa ia mampu mengatur secara mandiri setiap kebutuhan dalam proses belajar, sehingga dapat menunjukkan Self regulated learning yang baik.

Berdasarkan pembahasan mengenai pola asuh autoritatif yang tidak berperan secara signifikan terhadap Self regulated learning siswa Remaja SMA di Kabupaten Gianyar, dapat dirangkum bahwa pada masa remaja, peran orangtua tidak lagi seperti pada masa kanak-kanak, hal ini dikarenakan remaja cenderung lebih dekat dengan teman sebayanya. Remaja akan melihat dan meniru semua tindakan, gaya berpikir, dan tingkah laku yang dilakukan oleh teman sebayanya sehingga hal tersebut bisa memengaruhi perkembangan Self regulated learning.

Berdasarkan hasil deskripsi statistik data penelitian, subjek yang memiliki pola asuh autoritatif sangat tinggi 134 orang $(60,91 \%)$. Hal ini menunjukkan bahwa siswa remaja SMA di Kabupaten Gianyar memiliki orangtua yang mampu menyeimbangkan responsiveness dan demandingness. Taraf pola asuh autoritatif yang sangat tinggi berkaitan dengan pendidikan dan pekerjaan orangtua. Siswa remaja SMA di Kabupaten Gianyar memiliki orangtua yang berpendidikan menengah dan berpendidikan tinggi, terdapat 125 remaja memiliki ayah dengan pendidikan menengah, 85 remaja memiliki ayah dengan pendidikan tinggi, 139 remaja memiliki ibu dengan pendidikan menengah, dan 61 remaja memiliki ibu dengan pendidikan tinggi. Sejumlah 155 remaja memiliki ayah yang berprofesi sebagai swasta dan 50 remaja memiliki ayah yang berprofesi sebagai PNS, Polri, TNI-AD serta TNI-AU. Sejumlah 119 siswa remaja SMA di Kabupaten Gianyar memiliki ibu yang berprofesi sebagai swasta. Suwanti dan Suidah (2007) menyatakan bahwa pekerjaan dan latar belakang pendidikan berperan dalam penerapan pola asuh, dimana orangtua yang memiliki latar belakang pendidikan yang baik dan pekerjaan yang baik akan mampu menerapkan pola asuh yang baik terhadap anak-anaknya. Farida dan Naviati (2014) menambahkan bahwa orangtua yang berpendidikan menengah (SMA) dan tinggi (D1, D2, D3, D4, $\mathrm{S} 1$, S2, dan S3) biasanya akan cenderung menerapkan pola asuh yang baik yaitu pola asuh autoritatf.

Pada deskripsi statistik data penelitian menunjukkan 142 subjek memiliki taraf konsep diri tinggi sebesar 64,54\%. Tingginya taraf konsep diri yang dimiliki oleh siswa remaja SMA di Kabupaten Gianyar berkaitan dengan tempat subjek bersekolah. Sampai saat ini sekolah negeri masih menjadi sekolah yang lebih unggul dari sekolah swasta. Proses penerimaan untuk dapat masuk ke sekolah negeri juga cukup sulit yaitu dengan mengikuti tes TPA dan melalui seleksi hasil Nilai Ebtanas Murni (NEM). Subjek dalam penelitian ini telah berhasil dalam tes potensi akademik (TPA) yang dilakukan oleh sekolah dan NEM yang diperoleh juga tinggi sehingga subjek dapat diterima menjadi siswa. Hal ini membuat subjek menjadi bangga akan kemampuan yang dimilikinya karena subjek telah mampu masuk disekolah unggul. Pemaparan tersebut berkaitan dengan dimensi eksternal dari konsep diri yaitu diri pribadi. Fits (dalam Agustiani, 2009) menjelaskan bahwa diri pribadi merupakan perasaan atau persepsi seseorang tentang keadaan pribadinya, hal ini tidak dipengaruhi oleh kondisi fisik atau hubungan dengan orang lain, tetapi dipengaruhi oleh sejauh mana individu merasa puas terhadap pribadinya atau sejauh mana ia merasa dirinya sebagai pribadi yang tepat. Guru-guru disekolah juga menghargai prestasi yang diraih oleh siswa-siswinya, dimana siswa-siswi yang mengikuti lomba baik dalam bidang akademik maupun non-akademik akan diberikan penghargaan dari sekolah.

Self regulated learning siswa remaja SMA di Kabupaten Gianyar tergolong dalam taraf yang tinggi yaitu sebanyak 124 subjek (56,36\%). Tingginya taraf Self regulated learning pada siswa remaja SMA di Kabupaten Gianyar dapat disebabkan oleh tingginya taraf pola asuh autoritatif dan konsep diri pada penelitian ini. Hasil uji regresi berganda menyatakan bahwa pola asuh autoritatif dan konsep diri secara bersama-sama berperan terhadap Self regulated learning. Taraf pola asuh autoritatif dan konsep diri yang tergolong sangat tinggi maka akan berpengaruh juga pada tingginya taraf Self regulated learning siswa remaja SMA.

Saran bagi siswa yaitu siswa diharapkan mampu untuk mempertahankan konsep diri positif dengan mengikuti berbagai kegiatan organisasi dan ekstrakurikuler sehingga siswa dapat berinteraksi dengan teman-temannya dan bisa mengasah keterampilan serta kemampuan yang dimiliki, karena konsep diri yang positif sangat berperan terhadap Self regulated learning. Bagi orangtua diharapkan mampu memberikan perlakuan yang dapat meningkatkan konsep diri anak, hal ini dikarenakan konsep diri yang dimiliki anak akan memengaruhi perkembangan Self regulated learning. Orangtua dapat meningkatkan konsep diri anak dengan memberikan pujian dan apresiasi saat anak mampu mencapai suatu prestasi yang baik. Bagi pihak sekolah diharapkan dapat mendukung setiap kegiatan yang dilakukan oleh siswa dan memberikan apresiasi apabila siswa berhasil memperoleh suatu prestasi baik dibidang akademik maupun non-akademik, sehingga akan dapat meningkatkan kemampuan siswa dalam mengembangkan Self regulated learning dan prestasi siswa juga dapat meningkat.

Saran bagi peneliti selanjutnya yaitu ketika melakukan pengambilan data penelitian, sebaiknya dijadwalkan dengan baik agar tidak mengganggu proses belajar dan bisa menyesuaikan dengan kegiatan siswa seperti ujian kenaikan kelas, sehingga peneliti dapat mengawasi siswa dalam mengisi instrumen penelitian agar siswa mengisi instrumen penelitian 
dengan baik karena jawaban yang diberikan siswa sangat berpengaruh terhadap hasil penelitian. Peneliti selanjutnya yang akan mengambil tema yang sama tentang Self regulated learning, diharapkan untuk dapat memperluas wilayah populasi serta mencari subjek dan tempat populasi yang berbeda sehingga dapat memperoleh data yang lebih kaya.

\section{DAFTAR PUSTAKA}

Agustiani, H;. (2009). Psikologi Perkembangan. Bandung: Refika Aditama.

Ali, M; Asrori, M;. (2014). Psikologi Remaja. Jakarta: Bumi Aksara.

Azwar, S. (2013). Penyusunan Skala Psikologi. Yogyakarta: Pustaka Belajar.

Azwar, S. (2013). Reliabilitas dan Validitas. Yogyakarta: Pustaka Belajar.

Baumrind, D. (1966). Prototypical Descriptions of 3 Parenting Styles. Diunduh

dari

http://www.devpsy.org/teaching/parent/baumrindparentings tyles.pdf. Tanggal 27 Mei 2015.

Burns, R. B. (1993). Konsep diri. Jakarta: Arcan.

Cross, D R;. (2009). Parenting Style. Diunduh dari http://www.davidcross.us/classes/child/ParentingStyle.pdf. Tanggal 27 Mei 2015.

Darling, N;. (1999). Parenting style and its correlates. Diunduh dari http://www.kidneeds.com/diagnostic_categories/articles/par entcorrelates.pdf. Tanggal 27 Mei 2015.

Dinas Pendidikan, Pemerintah Provinsi Bali;. (2016, Mei 5). Penyampaian Daftar Kolektif Nilai Ujian Nasional Jenjang SMA/SMK Tahun Pelajaran 2015/2016. Diunduh dari www.disdikpora.baliprov.go.id. Tanggal 9 Agustus 2017.

Ellena, R S; Leonardi, T;. (2014). Perbedaan Self-regulated learning Siswa SMA Ditinjau dari Persepsi Terhadap Pola Asuh Orangtua. Jurnal Psikologi Pendidikan dan Perkembangan, $3(3)$.

Farida, L N; Naviati, E;. (2014). Hubungan Pola Asuh Otoritatif Dengan Perkembangan Mental Emosional Pada Anak Usia Prasekolah Di Tk Melati Putih Banyumanik. Diunduh dari jurnal.unimus.ac.id. Tanggal 15 Juni 2017.

Fauziah, N I;. (2007). Hubungan Antara Dukungan Sosial Dan Self regulated learning Pada Siswa SMP Homeschooling. Diunduh dari ilib.usm.ac.id. Tanggal 13 Juni 2017.

Feist, J; Feist, G J;. (2010). Psikologi Kepribadian. Buku 2. Edisi 7. Jakarta: Salemba Humanika.

Ghozali, H I. (2011). Aplikasi Analisis Multivariat dengan Program IBM SPSS. Semarang: Universitas Diponegoro.

Ghozali, H I;. (2005). Aplikasi Analisis Multivariate dengan Program SPSS. Semarang: Universitas Diponegoro.

Gunawan, M. A. (2013). Statistik Untuk Penelitian Pendidikan. Yogyakarta: Parama Publishing.

Huda. (2013). Pertumbuhan Fisik Dan Perkembangan Intelek Usia Remaja, (2).

Kopko, K;. (2007). Parenting styles and adolescents. Diunduh dari http://www.human.cornell.edu/pam/outreach/parenting/pare nts/upload/Parenting-20Styles-20and-20Adolescents.pdf Tanggal 27 Mei 2015.

Lestari, S. (2012). Psikologi Keluarga. Jakarta: Kencana.

Mahmudi, F; Mayangsari, M D; Rachmah, D N;. (2007). Hubungan Peer attachment Dengan Self regulated learning Pada Siswa Boarding School. Diunduh dari ppjp.unlam.ac.id. Tanggal 13 Juni 2017.

Monks, P.J; Knoers, A.M.P; Haditono, S R;. (2002). Psikologi Perkembangan. Yogyakarta: Gajah Mada University Press.

Mulyana, E; Mujidin; Bashori, K;. (2015). Peran Motivasi Belajar, Self-Efficacy, Dan Dukungan Sosial Keluarga Terhadap Self-regulated learning Pada Siswa. Psikopedagogia, 4 (1).
Nazir, M. (1988). Metode Penelitian. Jakarta: Ghalia Indonesia.

Papalia ; Old; Fieldman;. (2009). Human Development (Psikologi Perkembangan) Buku 2. Jakarta: Salemba Humanika.

Papalia, D E; Old, S W; Feldman, R D;. (2010). Human Development (Psikologi Perkembangan) Buku 1. Jakarta: Kencana.

Pratiwi, A P;. (2009). Hubungan Antara Kecemasan Akademis Dengan Self-regulated learning Pada Siswa Rintisan Sekolah Bertaraf Internasional Di SMA Negeri 3 Surakarta. Skripsi, Fakultas Psikologi Universitas Diponegoro Semarang.

Putri, P R A;. (2015). Hubungan Antara Self regulated learning Dan Kelekatan Remaja Awal Terhadap Ibu Dengan Prestasi Belajar Siswa SMP N 6 Denpasar. (Skripsi Tidak Dipublikasikan). Program Studi Psikologi Fakultas Kedokteran Universitas Udayana.

Putu;. (2013, Mei 24). Gianyar Raih 100\% Angka Kelulusan. Diunduh dari www.gianyarkab.go.id. Tanggal 9 Agustus 2017

Respati, W S; Yulianto, A; Widiana, A;. (2006). Perbedaan Konsep Diri Antara Remaja Akhir Yang Mempersepsi Pola Asuh Orang Tua Authoritarian, Permissive Dan Authoritative. Jurnal Psikologi, 4 (2).

Rini, A C;. (2017). Hubungan Antara Konsep Diri Dan Efikasi Diri Dengan Kemandirian Belajar Siswa. Artikel Skripsi. Diunduh dari https://simki.lp2m.unpkediri.ac.id. Tanggal 22 Juni 2017.

Ruliyanti, B D; Laksmiwati, H;. (2014). Hubungan Antara SelfEfficacy Dan Self-regulated learning Dengan Prestasi Akademik Matematika Siswa SMAN 2 Bangkalan. 3 (2).

Rustika, I M. (2014). Faktor-faktor yang mempengaruhi prestasi akademik pada remaja. (Disertasi tidak dipublikasikan). Program Doktor Psikologi Fakultas Psikologi Universitas Gajah Mada. Yogyakarta.

Santoso, S;. (2003). Mengatasi Berbagai Masalah Statistik dengan SPSS versi 11.5. Jakarta: Elex Media Komputindo.

Santrock, J. W. (2002). Life-Span Development (Perkembangan Masa Hidup). Jakarta: Erlangga.

Santrock, J. W. (2007). Remaja Jilid 1. Jakarta: Erlangga

Santrock, J. W. (2007). Remaja Jilid 2. Jakarta: Erlangga.

Sari, R P;. (2008). Hubungan Antara Pola Asuh Demokratis Dengan Prestasi Belajar Pada Remaja . Skripsi. Program Studi Psikologi Jurusan Psikologi Fakultas Psikologi Universitas Sanata Dharma Yogyakarta.

Sarwono, S W;. (2003). Pengantar Umum Psikologi. Jakarta: PT Bulan Bintang.

Schunk, D. H. (2005). Commentary on self-regulation in school contexts. Learning and Instruction, 15, 173- 177.

Schunk, D. H. (2005). Self-regulated learning: The educational legacy of Paul R. Pintrich. Educational Psychologist, 40, 85-94.

Setyani, U;. (2007). Hubungan Antara Konsep Diri Dengan Intensi Menyontek Pada Siswa SMA Negeri 2 Semarang. Skripsi. Program Studi Psikologi Fakultas Kedokteran Universitas Diponegoro Semarang.

Situmorang, Z R D; Latifah, M;. (2014). Pengaruh Dukungan Sosial, Konsep Diri, Dan Strategi Pengaturan Diri Dalam Belajar Terhadap Prestasi Akademik. Jurnal Ilmu Keluarga Dan Konsumen, 145-163, 7 (3).

Slavin, R E;. (2008). Psikologi Pendidikan Teori Dan Praktik. Jakarta: PT Indeks.

Spring;. (2008). Parental Authority and its Effect. Parenting for Moral Growth, 1(2).

Sugiyono. (2013). Statistika Untuk Penelitian. Bandung: Alfabeta.

Sugiyono. (2014). Metode Penelitian Kombinasi (Mixed Method). Bandung: Alfabeta.

Sugiyono. (2014). Metode Penelitian Kuantitatif Kualitatif Dan R\&D. Bandung: Alfabeta. 
Suryabrata, S. (2014). Metodologi Penelitian. Jakarta: RajaGrafindo Persada.

Suwanti, L; Suidah, H;. (2007). Hubungan Pola Asuh Orang Tua Dengan Mental Emosional Pada Anak Usia Prasekolah (4-6 Tahun). Jurnal Keperawatan \& Kebidanan.

Taylor, S E; Peplau, L A; Sears, D O;. (2009). Psikologi Sosial . Jakarta: Kencana.

Yudiaatmaja, F. (2013). Analisis Regresi. Jakarta: Gramedia Pustaka Utama.

Zimmerman, B J; Martinez-Pons, M;. (1988). Construct Validation of a Strategy Model of Student Self-regulated learning. Journal of Educational Psychology, 80 (3), 284-290.

Zimmerman, B J; Schunk, D H;. (2011). Handbook of SelfRegulation of Learning and Performance. New York and London: Routledge Taylor \& Francis Group.

Zimmerman, B J;. (1989). A Social Cognitive View of SelfRegulated Academic Learning. Journal of Educational Psychology, 81 (3). 329-339.

Zimmerman, B J;. (1989). A Social Cognitive View of SelfRegulated Academic Learning. Journal of Educational Psychology, 81 (3). 0022-0663.

Zimmerman, J;. (1990). Self-regulated learning and Academic

Achievement : An Overview. Educational Psychology, 25 (1), 3-17. 
P. D. PURWARINI \& I M. RUSTIKA

LAMPIRAN

Tabel 1

Penilaian Skala

\begin{tabular}{ccc}
\hline Pilihan Jawaban & Skor Aitem Favorable & Skor Aitem Unfavorable \\
\hline Sangat Setuju (SS) & 4 & 1 \\
\hline Setuju (S) & 3 & 2 \\
\hline Tidak Setuju (TS) & 2 & 3 \\
\hline Sangat Tidak Setuju (STS) & 1 & 4 \\
\hline
\end{tabular}


Tabel 2

Deskripsi Data Penelitian

\begin{tabular}{|c|c|c|c|c|c|c|c|c|}
\hline Variabel & $\mathbf{N}$ & $\begin{array}{l}\text { Mean } \\
\text { Teoretis }\end{array}$ & $\begin{array}{c}\text { Mean } \\
\text { Empiris }\end{array}$ & $\begin{array}{c}\text { Std. } \\
\text { Deviasi } \\
\text { Teoretis }\end{array}$ & $\begin{array}{c}\text { Std. } \\
\text { Deviasi } \\
\text { Empiris }\end{array}$ & $\begin{array}{l}\text { Sebaran } \\
\text { Teoretis }\end{array}$ & $\begin{array}{l}\text { Sebaran } \\
\text { Empiris }\end{array}$ & $\begin{array}{c}\text { t dan } \\
\text { signifikansi }\end{array}$ \\
\hline $\begin{array}{l}\text { Pola asuh } \\
\text { autoritatif }\end{array}$ & 220 & 67,5 & 89,83 & 13,5 & 9,938 & $27-108$ & $42-108$ & $\begin{array}{c}36,629 \\
(p=0,000)\end{array}$ \\
\hline Konsep diri & 220 & 92,5 & 110,79 & 18,5 & 9,043 & $37-148$ & $85-146$ & $\begin{array}{c}23,961 \\
(p=0,000)\end{array}$ \\
\hline $\begin{array}{l}\text { Self regulated } \\
\text { learning }\end{array}$ & 220 & 80 & 93,58 & 16 & 11,323 & $32-128$ & $69-125$ & $\begin{array}{c}20,264 \\
(p=0,000)\end{array}$ \\
\hline
\end{tabular}


Tabel 3

Kategorisasi pola asuh autoritatif

\begin{tabular}{cccc}
\hline Rentang nilai & Kategori & Jumlah & Persentase \\
\hline $\mathrm{X} \leq 47,25$ & Sangat Rendah & 1 & $0,45 \%$ \\
\hline $47,25<\mathrm{X} \leq 60,75$ & Rendah & 1 & $0,45 \%$ \\
\hline $60,75<\mathrm{X} \leq 74,25$ & Sedang & 7 & $3,19 \%$ \\
\hline $74,25<\mathrm{X} \leq 87,75$ & Tinggi & 77 & $35,0 \%$ \\
\hline $87,75<\mathrm{X}$ & Sangat Tinggi & 134 & $60,91 \%$ \\
\hline Total & & $\mathbf{2 2 0}$ & $\mathbf{1 0 0 \%}$ \\
\hline
\end{tabular}


Tabel 4

Kategorisasi konsep diri

\begin{tabular}{cccc}
\hline Rentang nilai & Kategori & Jumlah & Persentase \\
\hline $\mathrm{X} \leq 64,75$ & Sangat Rendah & 0 & $0 \%$ \\
\hline $64,75<\mathrm{X} \leq 83,25$ & Rendah & 0 & $0 \%$ \\
\hline $83,25<\mathrm{X} \leq 101,75$ & Sedang & 39 & $17,73 \%$ \\
\hline $101,75<\mathrm{X} \leq 120,25$ & Tinggi & 142 & $64,54 \%$ \\
\hline $120,25<\mathrm{X}$ & Sangat Tinggi & 39 & $17,73 \%$ \\
\hline Total & & $\mathbf{2 2 0}$ & $\mathbf{1 0 0 \%}$ \\
\hline
\end{tabular}


Tabel 5

Kategorisasi self regulated learning

\begin{tabular}{cccc}
\hline Rentang nilai & Kategori & Jumlah & Persentase \\
\hline $\mathrm{X} \leq 56$ & Sangat Rendah & 0 & $0 \%$ \\
\hline $56<\mathrm{X} \leq 72$ & Rendah & 3 & $1,36 \%$ \\
\hline $72<\mathrm{X} \leq 88$ & Sedang & 63 & $28,64 \%$ \\
\hline $88<\mathrm{X} \leq 104$ & Tinggi & 124 & $56,36 \%$ \\
\hline $104<\mathrm{X}$ & Sangat Tinggi & 30 & $13,64 \%$ \\
\hline Total & & $\mathbf{2 2 0}$ & $\mathbf{1 0 0 \%}$ \\
\hline
\end{tabular}


PERAN POLA ASUH AUTORITATIF DAN KONSEP DIRI

Tabel 6

Hasil uji normalitas data penelitian

\begin{tabular}{ccc}
\hline Variabel & Kolmogorov-Smirnov & Asymp.Sig (2-Tailed) \\
\hline Pola asuh autoritatif & 0,847 & 0,470 \\
\hline Konsep diri & 0,877 & 0,426 \\
\hline Self regulated learning & 1,227 & 0,099 \\
\hline
\end{tabular}


Tabel 7

Hasil uji linearitas data penelitian

\begin{tabular}{ccccc}
\hline & & F & Sig. \\
\hline $\begin{array}{c}\text { Self regulated learning } \\
\text { Pola asuh autoritatif }\end{array}$ & $\begin{array}{c}\text { Between } \\
\text { Groups }\end{array}$ & Linearity & 32,947 & 0,000 \\
& Deviation from Linearity & 1,926 & 0,003 \\
\hline $\begin{array}{c}\text { Self regulated learning } \\
\text { Konsep diri }\end{array}$ & $\begin{array}{c}\text { Between } \\
\text { Groups }\end{array}$ & Linearity & 120,625 & 0,000 \\
& & Deviation from Linearity & 1,413 & 0,057 \\
\hline
\end{tabular}


Tabel 8

Hasil uji multikolinearitas

\begin{tabular}{cccc}
\hline Variabel & Tolerance & $\begin{array}{c}\text { Variance Inflation } \\
\text { Factor (VIF) }\end{array}$ & Keterangan \\
\hline Pola asuh autoritatif & 0,798 & 1,252 & $\begin{array}{c}\text { Tidak terjadi } \\
\text { multikolinearitas }\end{array}$ \\
\hline Konsep diri & 0,798 & 1,252 & $\begin{array}{c}\text { Tidak terjadi } \\
\text { multikolinearitas }\end{array}$ \\
\hline
\end{tabular}


P. D. PURWARINI \& I M. RUSTIKA

Tabel 9

Hasil uji regresi berganda pola asuh autoritatif dan konsep diri terhadap self regulated learning

\begin{tabular}{cccc}
\hline $\mathbf{R}$ & R Square & Adjusted R Square & Std. Error of the Estimate \\
0,587 & 0,344 & 0,338 & 8,084 \\
\hline
\end{tabular}


Tabel 10

Hasil uji regresi berganda signifikansi nilai $\mathrm{F}$

\begin{tabular}{cccccc}
\hline Model & $\begin{array}{c}\text { Sum of } \\
\text { Square }\end{array}$ & df & Mean Square & F & Signifikansi \\
\hline Regression & 7449,867 & 2 & 3724,934 & 57,004 & 0,000 \\
\hline Residual & 14179,819 & 217 & 65,345 & & \\
\hline Total & $\mathbf{2 1 6 2 9 , 6 8 6}$ & $\mathbf{2 1 9}$ & & & \\
\hline
\end{tabular}


P. D. PURWARINI \& I M. RUSTIKA

Tabel 11

Hasil uji regresi berganda nilai koefisien beta dan nilai t variabel pola asuh autoritatif dan konsep diri

\begin{tabular}{cccccc}
\hline Model & \multicolumn{2}{c}{ Unstandardized Coefficients } & $\begin{array}{c}\text { Standardized } \\
\text { Coefficients }\end{array}$ & t & Signifikansi \\
\cline { 2 - 4 } & $\mathrm{B}$ & Std. Error & Beta & & \\
\hline (Constant) & 31,686 & 6,351 & & 4,989 & 0,000 \\
\hline $\begin{array}{c}\text { Pola asuh } \\
\text { autoritatif }\end{array}$ & 0,109 & 0,068 & 0,100 & 1,618 & 0,107 \\
\hline Konsep diri & 0,470 & 0,054 & 0,535 & 8,705 & 0,000 \\
\hline
\end{tabular}

